[2] V.A. Vittix, P.O. Skobelev "Multiagentnye modeli vzaimodejstviya dlya postroeniya setej potrebnostej i vozmozhnostej v otkrytyx sistemax”, avtomatizaciya i telemex., № 1, pp. 177-185,2002.

[3] P.O. Skobelev i dr. "primenenie ontologii v intellektualnoj sisteme raspredelennogo upravleniya malorazmernyx kosmicheskix apparatov”, izvestiya samarskogo nauchnogo centra ran, Vol. 17, № 2(5), pp. 1119-1130, 2015.

[4] P.O. Skobelev i dr. "Planirovanie celevogo primeneniya gruppirovki kosmicheskix apparatov distancionnogo zondirovaniya zemli s ispolzovaniem multiagentnyx texnologij”, izvestiya yufu. texnicheskie nauki, №10(171), pp. 60$70,2015$.

[5] P.O. Skobelev, "Otkrytye multiagentnye sistemy dlya operativnoj obrabotki informacii v processax prinyatiya reshenij”, Ph.D. dissertation, Dept. Tech, ICCS, Samara, Russia, 2003.

[6] J. Garcia et al., "Agent-based Coordination of Cameras", International Journal of Computer Science and Applications,vol. 2, pp. 33-37, Jan. 2005.

[7] M. Laclavik et al. "Agent OWL: Semantic knowledge model and agent architecture", Computing and Informatics, vol. 25, pp. 419-437, May. 2006.

[8] K.S. Vivek et al., "Coopetitive multi-camera surveillance using model predictive control", Machine Vision and Applications, vol. 19, pp. 375-393, Oct. 2008.

[9] FIPA Abstract Architecture Specification, SC00001L, 2002.

УДК 621.86.08-52

\title{
ІМІТАЦІЙНА МАТЕМАТИЧНА МОДЕЛЬ КОНВЕСРНИХ ВАГОВИМІРЮВАЧІВ ДОЗАТОРІВ БЕЗПЕРЕРВНОЇ ДІЇ
}

\author{
Д.В. Дец ${ }^{1}$, К. Шейда-Голбад ${ }^{2}$, В.А. Хобін ${ }^{3}$ \\ 1,2,3 Одеська національна академія харчових технологій, Україна \\ ORCID: ${ }^{1}$ 0000-0002-8556-5451, ${ }^{3} 0000-0003-0238-8371$ \\ E-mail: ${ }^{1}$ dec@onaft.edu.ua, ${ }^{2}$ kambiz@ukr.net, ${ }^{3}$ khobin@ onaft.edu.ua \\ Copyright (C 2017 by author and the journal “Automation technological and business - processes”. \\ This work is licensed under the Creative Commons Attribution International License (CC BY). \\ http://creativecommons.org/licenses/by/4.0/
}

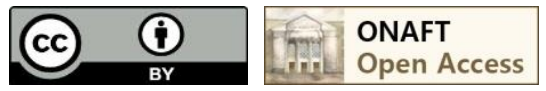

Анотація: У статті розглянуто імітачійне моделювання конвеєрних ваговимірювачів дозаторів безперервної дії у середовищі MATLAB\Simulink. Такі дозатори атестуються метрологічними службами як вимірювальні пристрої. Це вимагає точного відображення моделюємих властивостей ваговимірювачів. Отриманий комплекс імітаційних ичифрових моделей прочесів переміщення та зважування дозуємого сипучого матеріалу, які реалізує конвеєрний ваговимірювач, дозволить проводити коректні машинні експерименти для розробки та тестування ефективних алгоритмів керування автономними дозаторами та їхніми комплексами.

Abstract: In the article simulation modeling of conveyor weight meters of continuous batchers in MATLAB $\backslash$ Simulink environment is considered. Such batchers are certified by metrological services as measuring devices. It requires an accurate reflection of the simulated properties of the weight meters. The obtained complex of imitation digital models of the processes of movement and weighing of the batchered bulk material, which the conveyor weighing meters are realized, allows to conduct correct machine experiments for the development and testing of effective control algorithms by autonomous batchers and their complexes.

Ключові слова: дозатор, вагове безперервне дозування, конвеєрний ваговимірювач, імітаційна математична модель.

Keywords: feeder, weight continuous dosing, conveyor belt scales, simulation modeling. 
Вступ http://www.atbp.onaft.edu.ua/

Формування сумішей сипучих матеріалів є складовою частиною технологічних процесів (ТП) багатьох галузей промисловості: металургійної, будівельних матеріалів, комбікормової та ін. Відповідність отриманої суміші заданому рецепту в істотній мері визначає якість готової продукції, а продуктивність ТП - пї собівартість.

Комплекси конвеєрних вагових дозаторів безперервної дії (КВДБД) знайшли в цих галузях широке застосування завдяки ряду переваг у порівнянні з дозаторами дискретної дії (порційними). Це, насамперед, істотно більш висока продуктивність, більш низькі енерговитрати, висока однорідність суміші при простій конструкції змішувача, малі габарити та вага, зручність компонування в технологічні лінії. Істотним недоліком КВДБД є, як правило, більш низька точність дозування компонентів суміші та дозування тільки легкосипучих слабоабразивних матеріалів.

Підвищення конкурентноздатності безперервних технологій сумішоприготування в умовах зростаючих вимог до якості суміші та ускладнення їхньої рецептури (збільшення кількості компонентів у суміші) можливо тільки при підвищенні якості формованої ними суміші. Перспективним та економічним напрямком вирішення цієї проблеми $є$ удосконалення систем автоматичного керування (САК) КВДБД, що вимагає цілеспрямованих досліджень для виявлення схованих закономірностей, що знижують точність дозування, та розробки алгоритмів керування, що враховують ці закономірності.

Незважаючи на уявну простоту КВДБД є досить складною нелінійною динамічною системою зі змінними параметрами. Це різко обмежує область аналітичних досліджень. Дослідження на діючих дозаторах або їхніх фізичних моделях також принципово обмежені. Справа у тому, що одну з найважливіших змінних - фактичну продуктивність дозатора, тобто продуктивність у точці скидання, практично неможливо вимірити. Це зумовлює доцільність використання методів імітаційного моделювання як ефективного інструмента для проведення досліджень САК КВДБД та комплексів на їхній основі.

Спрощену схему КВДБД наведено на рис. 1. Його імітаційна модель містить у собі:

- модель конвеєрного ваговимірювача (містить моделі: а) витікання дозуємого матеріалу на стрічку конвеєрного ваговимірювача 3 наддозаторного бункеру; б) переміщення матеріалу стрічкою конвеєра по його ділянках (подачі, ваговимірювання, скидання); в) накопичення матеріалу на ваговимірювальній ділянці та виміру продуктивності; г) електроприводу з регульованою швидкістю);

— модель регулюючого пристрою, що реалізує алгоритм керування дозатором.

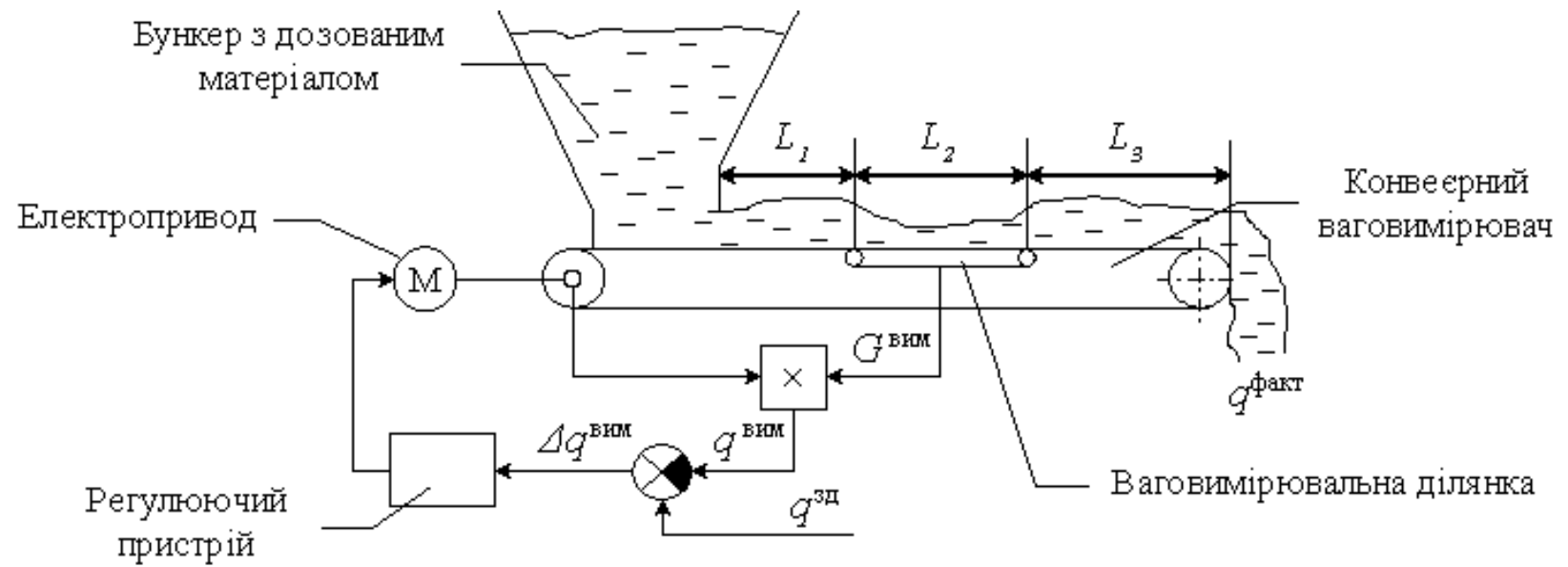

Рис. 1 - Схема конвесрного вагового дозатора безперервної дії

Модель витікання матеріалу

До цієї моделі пред'являлися наступні вимоги:

- процес, що моделюється, повинен мати властивості тестового процесу для проведення порівняльних досліджень, тому він повинен ідентично відтворюватися у кожному експерименті;

- властивості процесів витікання, що моделюються, повинні бути досить складними для керування, широкими за спектральним складом, щоб виключити «сприятливі збіги обставин»;

- моделі процесів витікання, що входять до комплексу, повинні бути некорельованими між собою.

Вона прийнята у вигляді наступної суми:

$$
G_{0}(t)=\bar{G}(t)+G_{\Gamma}(t)+G_{C 1}(t)+G_{C 2}(t)+G_{C 3}(t),
$$

де $\bar{G}(t), G_{\Gamma}(t), G_{C 1}(t) \ldots G_{C 3}(t)$ - відповідно постійна, гармонійна та випадкова складові моделі.

Схему цифрової імітаційної моделі процесу витікання матеріалу з наддозаторного бункеру на стрічку конвеєрного ваговимірювача, тобто формування моделі $G_{0}(t)$, наведено на рис. 2. 


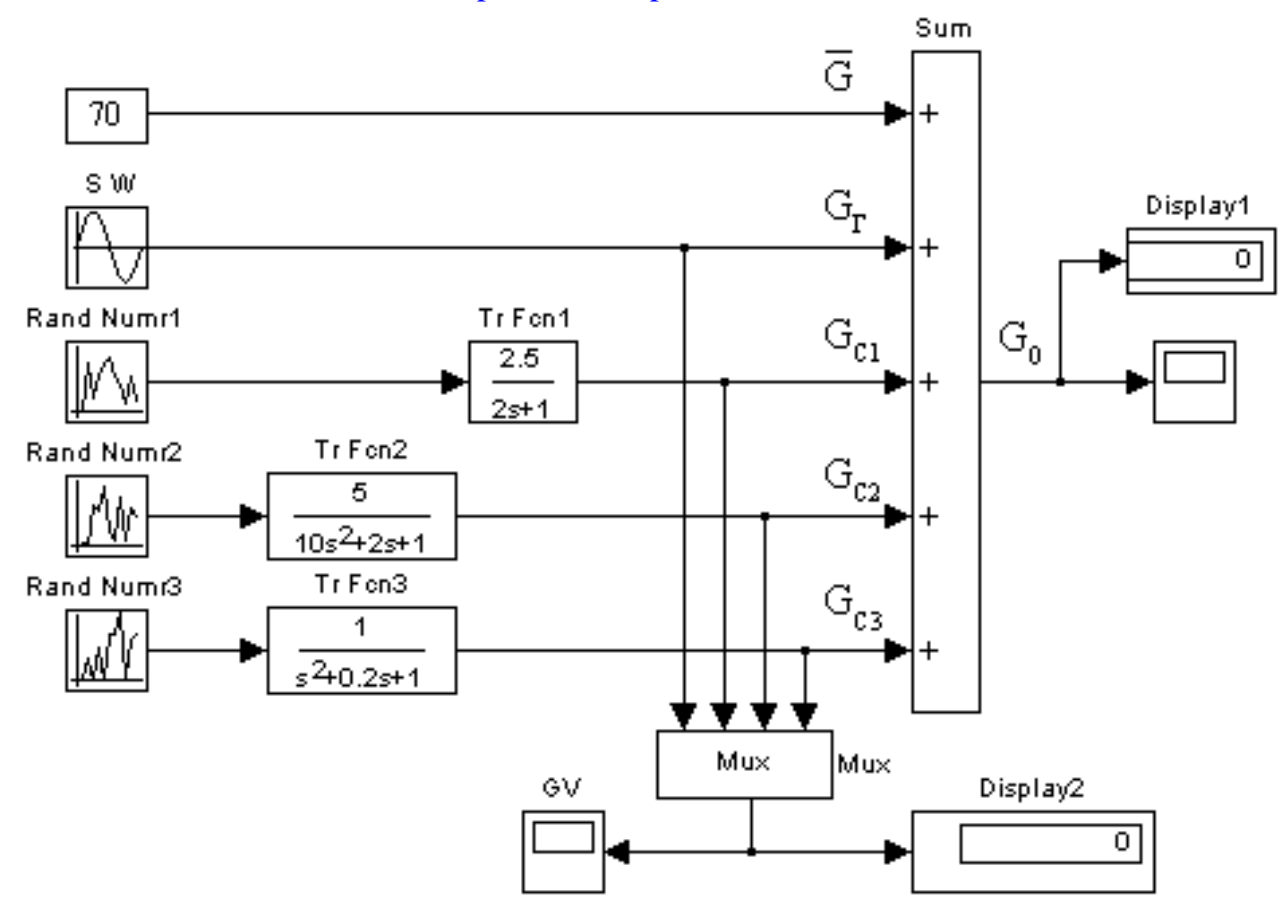

Рис. 2 - Схема моделювання витікання дозусмого матеріалу на стрічку ваговимірвального конвесра

Складові змінної $G_{0}(t)$ формуються на основі модулів розділів Sources та Linear бібліотеки Simulink (тут і далі пакет MATLAB $5.2[1,2])$. Для реалізації випадкових складових із заданими властивостями використовувався метод формуючих фільтрів [3], тобто задані властивості випадкових процесів формувалися пропущенням базових випадкових процесів через лінійні динамічні ланки.

Слід зазначити, що для реалізації вище перерахованих вимог до тестового $G_{0}(t)$ зроблено наступне:

a) збільшено кількість складових у $G_{0}$ до п'яти, при цьому три з них $є$ випадковими процесами з істотно різними властивостями;

б) передбачено можливість заміни гармонійної низькочастотної складової на «пилоподібну»;

в) базові генератори випадкових складових процесу взято різними та запускаються з фіксованих початкових точок;

г) компоненти $G_{i}(t)$ для різних дозаторів формуються з різними властивостями, у т.ч. генератори коливань та базових випадкових процесів запускаються з різних початкових фаз та точок.

Приклад характеристик $G_{0}(t)$ одного компонента як тестової моделі для досліджень КВДБД наведено на рис. 3 та 4. Параметри формуючих фільтрів моделей наведено на рис. 2.

Модель переміщення матеріалу стрічкою

Містить моделі його переміщення трьома ділянками стрічки - від його витікання з наддозаторного бункеру до скидання з конвеєра:

— ділянка подачі матеріалу з бункеру на ваговимірювальну ділянку, довжина $L_{l}$; маса наприкінці ділянки $G_{l}$;

— ділянка руху матеріалу по ваговимірювальній ділянці, довжина $L_{2}$, маса наприкінці ділянки $G_{2}$; $G_{3}$.

— ділянка скидання матеріалу з конвеєра, довжина $L_{3}$, маса наприкінці ділянки, тобто в точці скидання матеріалу

Принципово важливою особливістю, яку необхідно відобразити в моделі, є те, що дозуємий матеріал розподілено за довжиною стрічки, причому час перебування його на стрічці та спектральний склад коливань маси на будь-якій ділянці стрічки будуть залежати від миттєвих значень ії швидкості.

Основу моделей переміщення матеріалу стрічкою конвеєра та накопичення матеріалу на ваговимірювальній ділянці складає процедура обчислення часу $\tau_{i}(t)$ перебування матеріалу (часу транспортного запізнення) на характерних ділянках стрічки: ваговимірювальній, скидання. Звичайно при імітаційному моделюванні час перебування матеріалу на ділянці стрічки довжиною $L_{i}$ при швидкості іiі руху $v(t)$ розраховувалося з виразу:

$$
\tau_{i}(t)=\frac{L_{i}}{v(t)},
$$

що $є$ некоректним та може застосовуватися тільки для випадків, коли за час $\Delta \tau_{i}$ зміни $\Delta v\left(t, \Delta \tau_{i}\right)=v(t)-v\left(t+\Delta \tau_{i}\right)$ малі. Для моделювання систем регулювання продуктивності з істотно нерівномірним розподілом матеріалу за довжиною стрічки використовувати (2) неприпустимо. 

http://www.atbp.onaft.edu.ua/
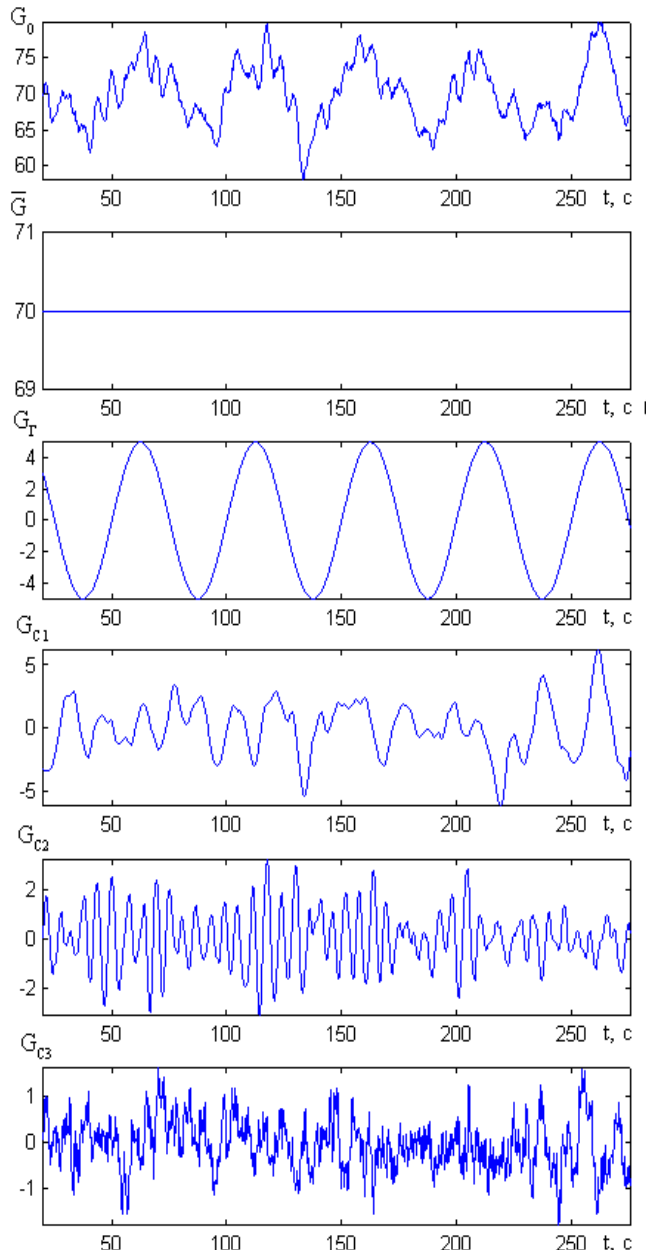

a)
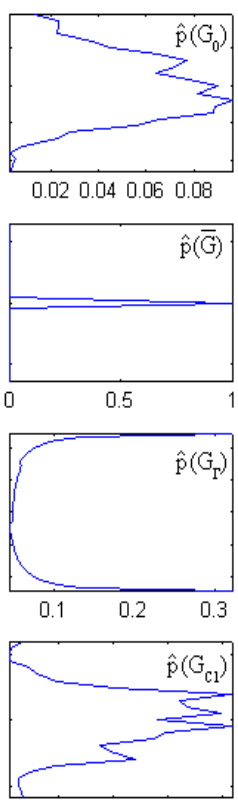

$\begin{array}{llll}0.05 & 0.1 & 0.15 & 0.2\end{array}$
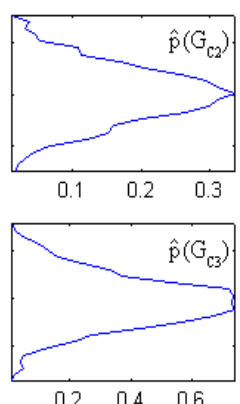

б)
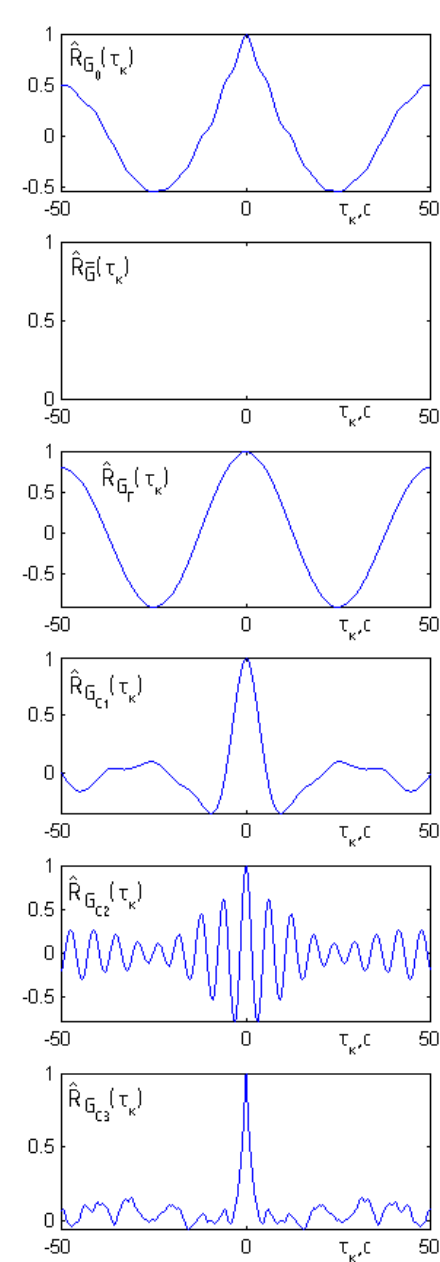

a)
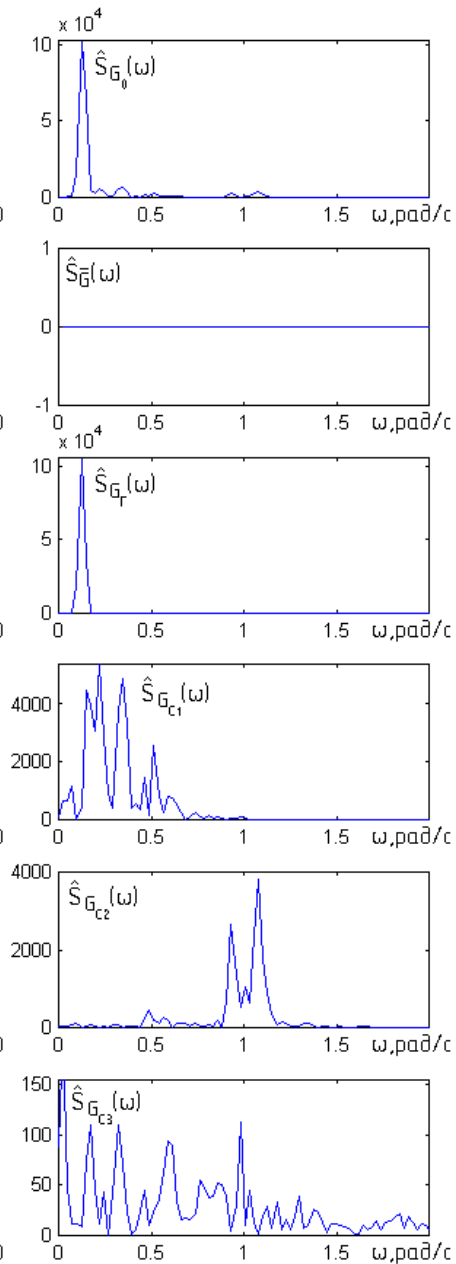

б)

Рис. 2 - Фрагмент реалізації тестової моделі процесу витікання G0(t) дозуємого матеріалу на стрічку КВДБД та його складових:

а) часові діаграми; б) оцінка щільностей імовірності

Рис. 3 - Оцінки автокореляційних функцій (a) та спектральних щільностей (б) змінної Go та її складових (відповідно до рис. 2)

Для розрахунку $\tau_{i}(t)$ розроблено спеціальний алгоритм, що реалізує вираз (3). Його сутність полягає у визначенні такого поточного часу транспортного запізнення $\tau_{i}(t)$ [4-6], що моделює перебування матеріалу на ділянці стрічки, при якому різниця інтегралів швидкості за часом на вході та виході блоку запізнення буде дорівнювати довжині ділянки, що моделюється:

$$
\tau_{i}(t)=\arg \left\{\int_{0}^{t} v(t) d t-\int_{0-\tau_{i}}^{t-\tau_{i}} v(t) d t=L_{i}\right\} .
$$

Схему обчислення $\tau_{i}(t)$, що реалізує (3) у середовищі Simulink, наведено на рис. 4 (використовуються модулі розділів бібліотеки Linear та Nonlinear). Регулятор у ланцюгу зворотного зв'язку, що забезпечує рівність фігурних дужок, що складаються, крім пропорційної складової (з дуже великим коефіцієнтом передачі) має й інтегруючу, призначення якої - забезпечити максимальну статичну точність [7].

Модуль обмеження $\tau^{\prime}$ використовується для прискорення загасання перехідних процесів на початку моделювання. Для усунення погрішностей, пов'язаних з ними, починати «активне» моделювання доцільно після закінчення цих перехідних процесів. Ілюстрацію застосування формул (2) та (3) для $v(t)=0.8+0.2 \sin (\omega t)$, де $\omega_{1}=1, \omega_{2}=0.5$ рад/с, $L=$ 1 м наведено на рис. 5 (графіки 1 та 2 відповідно). 3 них витікає, що використання розрахунку $\tau_{i}(t)$ за $(2)$ дає дуже велику погрішність, причому зростаючу з ростом швидкості зміни $v(t)$. 


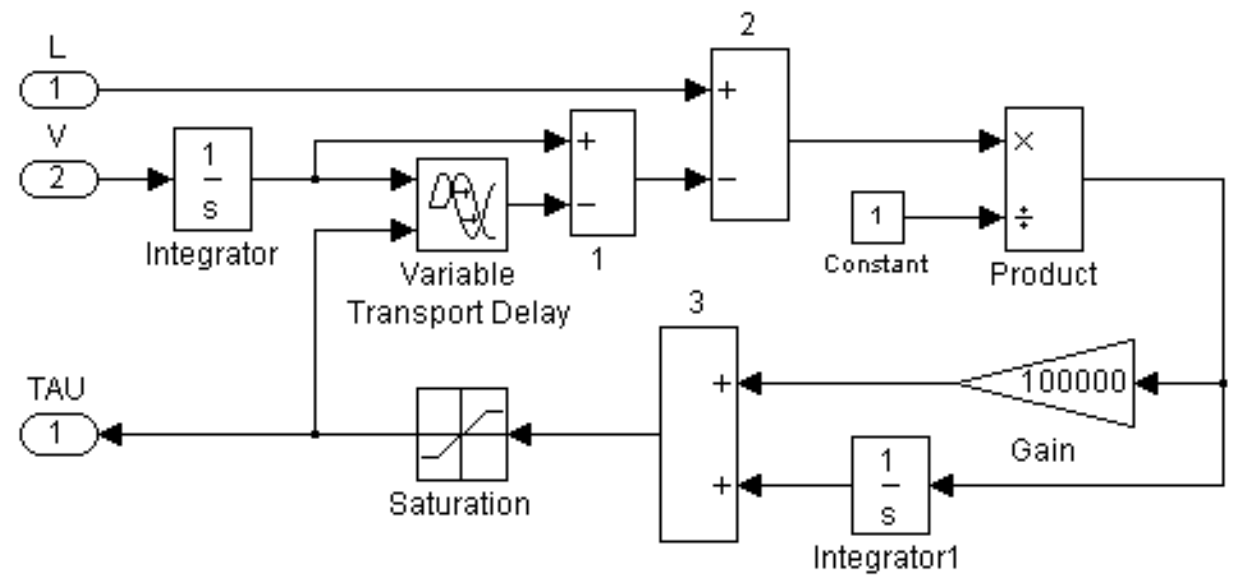

Рис. 4 - Схема обчислення часу перебування $\tau$ матеріалу на ділянці стрічки при змінній швидкості її руху за (3)

Модель конвесрного ваговимірювача

Як прототип для моделювання було обрано дозатор безперервної дії 4488, що випускається Одеським виробничим об'єднанням ВО «Точмаш», для якого довжина ваговимірювальної ділянки $L_{2}=1$ м, а довжина ділянки скидання матеріалу з конвеєра $L_{3}=0,7$ м. Максимальна швидкість руху стрічки транспортера 1 м/с. Враховуючи, що ланки змінного запізнення при моделюванні потребують істотно більшого ресурсу часу, чим інші ланки, і те, що перша ділянка не надає принципового впливу на результати моделювання, оскільки лише зміщає збурення у часі, було вирішено відмовитися від його моделювання, тобто прийняти $L_{1}=0$.
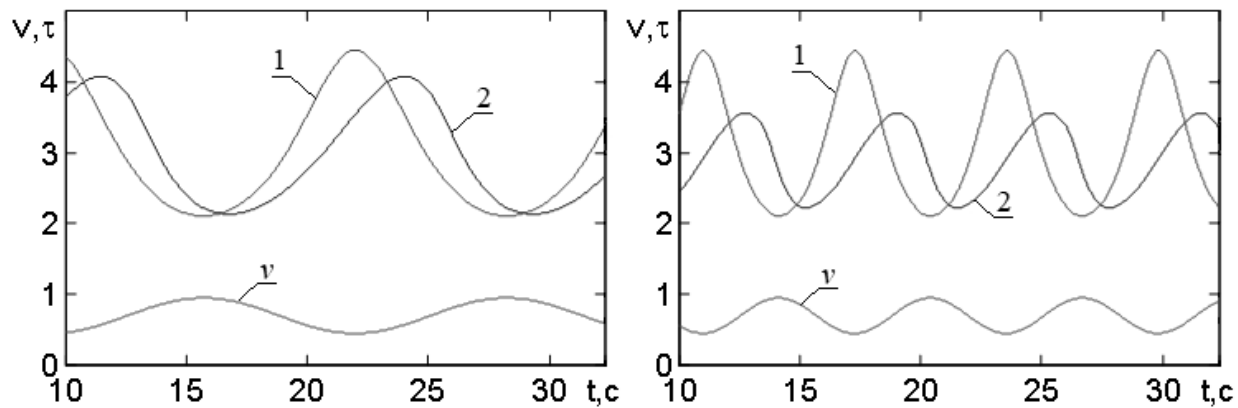

Рис. 5 - Ілюстрація обчислень поточного значення часу перебування матеріалу на ваговимірювальній ділянці стрічки: 1 - розрахунок за (2); 2 - розрахунок за (3)

Основу моделі складають ланки змінного запізнення, які розміщено у підрозділі бібліотеки Nonlinear. Оскільки моделювання змінного запізнення містить у собі, як основну складову перетворення, розмір масиву даних, то на діапазон зміни запізнення накладаються обмеження. Для розглянутого нами випадку важливим наслідком цього є те, що цілком змоделювати пусковий режим роботи дозатора неможливо. При $v(t)=0 \quad \tau \rightarrow \infty$, що потребує створення масиву з нескінченої кількості елементів.

Для моделі було взято діапазон запізнень $\tau_{2} \in[1 \ldots 10] \mathrm{c}, \tau_{3} \in[0,7 \ldots 7] \mathrm{c}$, що відповідає діапазону швидкості $v \in$ $[0,1 \ldots 1] \mathrm{M} / \mathrm{c}$. Значення початкових умов ланок запізнення приймалися нульовими, що відповідає ситуації включення дозаторів не завантаженими (на холостому ході).

Кожен «зріз» (питома маса) матеріалу, що дозується та надходить на ваговимірювальну ділянку, знаходиться там час перебування $\tau_{2}(t)$, що безперервно перерозраховується, рухається по ньому з поточною швидкістю $v(t)$ та залишає його, коли $l(t)=L_{2}$. Тоді накопичене та те, що знаходиться на ваговимірювальній ділянці стрічки значення маси матеріалу моделювалося інтегруванням за часом різниці поточних значень питомих мас матеріалу на вході та виході ваговимірювальної ділянки $L_{2}$, помноженої на поточну швидкість. Розрахунок вимірюваних значень маси та продуктивності припускає приведення маси матеріалу на ваговимірювальній ділянці довжиною $L_{2}$ до маси на довжині в 1 м та множення їі на величину поточного значення швидкості, що виражається в м/с. Це було реалізовано й у моделі.

Модель електроприводу

Вона описує динаміку каналу « $v^{3 \partial}-v »$, яку прийнято у вигляді лінійної передаточної функції:

$$
W^{E \Pi}(p)=\frac{1}{(0.1 p+1)^{2} \cdot(0.05 p+1)^{2}} .
$$


Обмеження швидкості відображають реальний діапазон зміни швидкості стрічки конвеєра: «верхнє» $v^{\text {гр+ }}=1 \mathrm{~m} / \mathrm{c}$ та «нижнє» $-v^{\text {гр- }}=0.1 \mathrm{~m} / \mathrm{c}$. Обмеження $v^{\text {гр- }}$ одночасно необхідне для забезпечення працездатності моделей ланок змінного запізнення.

Структурну схема імітаційної моделі конвеєрного ваговимірювача з моделлю електроприводу, у тому вигляді як вона надається користувачу у середовищі MATLAB, пакет Simulink, наведено на рис. 6.

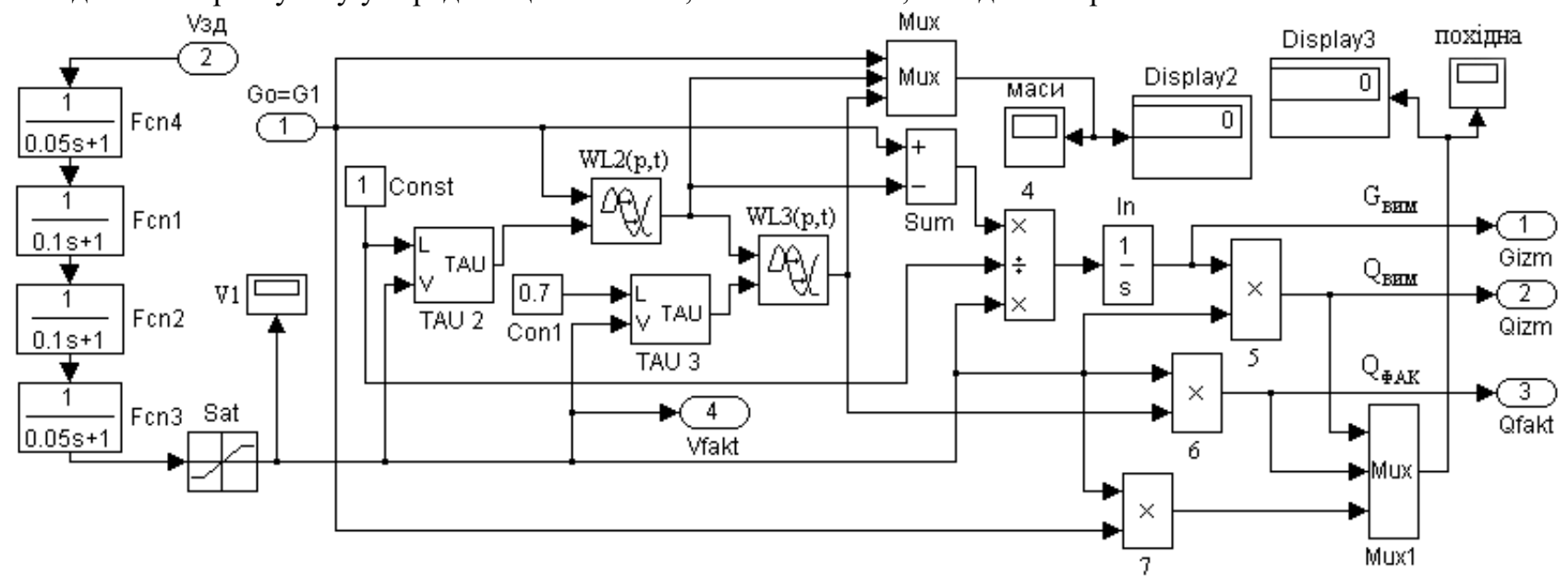

Рис. 6 - Схема моделювання переміщення матеріалу стрічкою конвесра, його накопичення ваговимірювальною ділянкою, руху стрічки від електроприводу та обчислення вимірюваних значень маси та продуктивності

Результати тестування моделі

Проведене тестування моделей показало їхню високу точність. Воно проводилося порівнянням мас віддозованого матеріалу в різних перерізах ваговимірювального конвеєра: на його вході, за результатами виміру на обчислювальній ділянці; та в перерізі скидання в умовах збурень по витіканню сипучого матеріалу на стрічку конвеєра. Розрахунок цих мас здійснювався інтегруванням змінних $G_{0}=G_{1}, G_{2}, G_{3}$. Базою для порівняння був варіант дозування, коли збурення відсутні, тобто коли $G_{0}=\bar{G}=$ const. При запропонованому визначенні маси сипучого матеріалу на ваговимірювальній ділянці конвеєра погрішність моделювання не перевищувала 0,2\%. При цьому реальний дозатор безперервної дії 4488 при метрологічних випробуваннях було атестовано як вимірювальний пристрій, що має максимально припустиму погрішність $1 \%$.

Висновок

Отримана імітаційна модель конвеєрного ваговимірювача дозаторів безперервної дії дозволить проводити коректні комп'ютерні експерименти та може бути основою для розробки та тестування ефективних алгоритмів керування автономними дозаторами та їхніми комплексами.

\section{Лiтература}

[1] Лазарев Ю. Ф. MatLAB 5.x / Ю. Ф. Лазарев // К.: Изд. группа ВНV, 2000. - 384 с.

[2] Дьяконов B. MATLAB. Анализ, идентификация и моделирование систем. Специальный справочник / В. Дьяконов, В. Круглов // СПб.: Питер, 2002. - 448 с.

[3] Шалыгин А. С. Прикладные методы статистического моделирования / А. С. Шалыгин, Ю. И. Палагин // Л.: Машиностроение. Ленингр. отд-ние, 1986. - 320 с.

[4] Солодов В. А. Системы с переменным запаздыванием / В. А. Солодов, Е. А. Солодова // М.:Наука, 1980. - 384 с.

[5] Грехова Л. И. Дискретная модель транспортного запаздывания: Каталог программных модулей. Специализированный межотраслевой фонд алгоритмов и программ. ВПО «Союзпромавтоматика», Киевское ПКБ АСУ / Л. И. Грехова // К., 1983. - 48 с.

[6] Хобин В. А. Моделирование звена с переменным временем запаздывания на ЭЦВМ / В. А. Хобин, А. Г. Плеве, С. Ю. Митрофанов // Указ. ВИНИТИ деп. рукописи, 1985, № 7. - 181 с.

[7] Нетушил А. В. Теория автоматического управления: Нелинейные системы управления при случайных воздействиях: Учеб. для вузов / А. В. Нетушил, А. В. Балтрушевич, В. В. Бурляев и др.; Под ред. А. В. Нетушила. - 2-е изд., перераб. и доп. // М.: Высш. шк., 1983. - 432 с.: ил.

References

[1] Yu. F. Lazarev, “MatLAB 5.x”, K., Izd. gruppa VNV, 2000.

[2] V. D'jakonov, V. Kruglov , "MATLAB. Analiz, identifikacija i modelirovanie sistem. Special'nyj spravochnik” SPb., Piter, 2002.

[3] A. S. Shalyigin, Yu. I. Palagin, "Prikladnyie metodyi statisticheskogo modelirovaniya”, L., Mashinostroenie, Leningr. 
otd-nie, 1986.

[4] V. A. Solodov, E. A. Solodova, "Sistemyi s peremennyim zapazdyivaniem”, M., Nauka, 1980.

[5] L. I. Grehova, "Diskretnaya model transportnogo zapazdyivaniya: Katalog programmnyih moduley. Spetsializirovannyiy mezhotraslevoy fond algoritmov i programm. VPO «Soyuzpromavtomatika»", Kievskoe PKB ASU, K., 1983.

[6] V. A. Khobin, A. G. Pleve, S. Yu. Mitrofanov, "Modelirovanie zvena s peremennyim vremenem zapazdyivaniya na ETsVM", Ukaz. VINITI dep. rukopisi, 1985, vol. 7.

[7] A. V. Netushil, A. V. Baltrushevich, V. V. Burlyaev i dr., "Teoriya avtomaticheskogo upravleniya: Nelineynyie sistemyi upravleniya pri sluchaynyih vozdeystviyah: Ucheb. dlya vuzov”, 2-e izd., pererab. i dop., M., Vyissh. shk., 1983.

\title{
ОСОБЛИВОСТІ НАЛАШТУВАННЯ СЕD-ПРОГРАМ ДЛЯ ПІДВИЩЕННЯ ЕФЕКТИВНОСТІ МОДЕЛЮВАННЯ ВИТРАТОМІРІВ
}

\author{
Ф.Д. Матіко1, В.І. Роман², О.Я. Масняк³ \\ 1,2,3 Національний університет «Львівська політехніка», Україна \\ ORCID: ${ }^{1}$ 0000-0001-6569-2587, ${ }^{2}$ 0000-0002-8546-6752 \\ Scopus ID: ${ }^{1} 29068004100$ \\ E-mail: ${ }^{1}$ fmatiko@gmail.com, ${ }^{2}$ roman_vitaliy@ukr.net, ${ }^{3}$ o_masnyak@ukr.net
}

Copyright (C 2017 by author and the journal "Automation technological and business - processes". This work is licensed under the Creative Commons Attribution International License (CC BY). http://creativecommons.org/licenses/by/4.0/

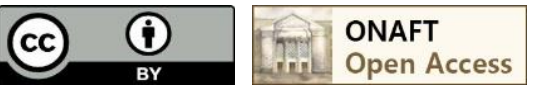

Анотація: В даній роботі авторами проведено дослідження ряду параметрів налаштовування CFD-програми Flow Simulations CAПP SolidWorks для підвищення ефективності моделювання ультразвукових витратомірів та витратомірів змінного перепаду тиску. За результатами роботи авторами запропоновано критерій точності відтворення масової витрати засобами СFD-моделювання та визначено діапазони значень параметрів налаштування CFD-програми Flow Simulations CAПP SolidWorks: вибрано оптимальний тип граничних умов на вході $i$ виході трьохвимірного макету вимірювальної ділянки трубопроводу з витратоміром певного типу; місие встановлення вхідного перерізу витратоміра; мінімально-достатнє значення рівня дроблення базової розрахункової сітки; відстань між твірними модифікованої сітки тривимірного макету. Запропоновані авторами рекомендації дають можливість забезпечити відтворення масової витрати під час моделювання газодинамічних явищ у розглянутих витратомірах з похибкою, щзо не перевищує $1 \%$, при мінімально можливій тривалості розв'язування моделі. Це дозволяє підвищити ефективність моделювання витратомірів за допомогою CFD-nрограми Flow Simulations CAПP SolidWorks. Результати роботи особливо актуальні при використанні засобів обчислювальної гідродинаміки для проведення обмежених за часом навчальних занять студентів технічних спеціальностей, зокрема в галузі автоматизаиії та комп'ютерно-інтегрованих технологій. Наведені авторами роботи рекомендаиії щяодо програмних налаштування Flow Simulations CAПP SolidWorks можуть бути інтерпретовані як для розглянутої, так $i$ інших CFD-програм що застосовуються для вирішення наукових прикладних задач ультразвукової витратометрії та витратомірів змінного перепаду тиску. 